\title{
Take lots with alcohol
}

\section{Karlie Moyle}

She lived under a bridge on the outskirts of town

And wore cigarette burns on the shirts of men much taller than her.

She rode an old yellow bicycle to match her grin -

And she bared her teeth at dogs.

Her eyes sunk deep into her skull

And shone like emeralds in the glistening sun.

She wore silver duct-tape around the toes of her shoes -

And she spent Christmas alone.

She drank Tennessee Whisky

And smoked Stuyvesant Gold.

She sung Johnny Rebel tunes for the local kids -

And she hated the colour red.

She wrote poetry under that big, old bridge

And would howl it, like a stray dog at the night sky.

She taught the kids that there was no god -

And she marched around in the rain.

She was charged with prostitution the night the policeman came.

And during her time in prison she ate three meals a day -

And developed a heroin addiction.

And she burned her poems on the day she died.

And she lay in the kind of coffin that the state provides.

And the poppies on her grave were red. 